DOI 10.18551/rjoas.2021-12.16

\title{
FINANCIAL ANALYSIS OF WASHING MACHINE PORANG (AMORPHOPHALLUS MUELLERI BLUME.) IN P4S KARYA TANI OF SOUTH SUMATRA, INDONESIA
}

\author{
Bidarti A.*, Yulius, Purbiyanti E., Januarti I. \\ Department of Agricultural Socio-Economics, University of Sriwijaya, Indonesia \\ *E-mail: agustinabidarti@unsri.ac.id
}

\begin{abstract}
The development of a washing machine porang's (Amorphophallus muelleri Blume.) in P4S Karya Tani Ogan Ilir was the starting point for this research. This machine's development must be followed by a techno-economic financial analysis. As a result, this research is a techno-economic financial analysis of washing machine porang's at P4S Karya Tani in South Sumatra. Based on the results and discussion, a washing machine porang's can be said to be a washing machine porang's. This machine can be used as a manual wash by a single person. The average capacity of a washing machine porang's was $6.5 \mathrm{~kg} / \mathrm{hour}$, with a 90 percent washing efficiency. When the washing machine is 2 years and 2 months old, the techno-economic financial feasibility test of a decent porang's is where the initial investment cost can be addressed. Furthermore, in terms of techno-economic capacity, the tuber is worth running once it can produce $975.5(\mathrm{~kg})$ tubers or the tool has earned 5750275.25 IDR.
\end{abstract}

\section{KEY WORDS}

Financial analysis, washing machine porang's, techno-economy, P4S.

Tanjung Batu Village, Tanjung Batu Subdistrict, Ogan Ilir Regency, South Sumatra Province is one of the villages in Indonesia that has a P4S Karya Tani of the NonGovernmental Rural Agriculture Training Center. Porang's plants, in addition to rubber plants, are being developed. Porang's produced by P4S Karya Tani farmers in Tanjung Batu Village are expected to make this village a center for porang's in South Sumatra Province as well as the primary producer of quality porang's.

The porang plant (Amorphophallus muelleri Blume.) is a member of the Araceae family. Porang's frequently confuse it as an araceae family with other araceae families, such as Ilesiles (Amorphophallus ancophillus), suweg (Amorphophallus companulatus), and walur (Amorphophallus variabilis) (Siswanto \& Karamina, 2016) Porang's have spathe and spadix in their flowers, which distinguishes porang (Amorphophallus muelleri Blume.) from other groups of araceae families. Porang's have bulbyls at the junction of veins with the highest glucomannan content, which distinguishes them from other Amorphophallus species. The bulbs on porang's plants are dark brown, with yellow to orange bulb meat (Anturida et al., 2015; Lontoh et al., 2019).

Porang's plants, also known as shrub plants, are easy to grow in the forest, dry land, and water. Porang's plants can also be grown in the shade of the rubber plant stands. Because of their high glucomannan content, porang's tubers are now widely cultivated into plants with high economic value. Porang's tubers can be used in a variety of industrial applications such as glue materials, capsule wrapping, paper boosters, and so on. The bulbs are processed by making flour from them (Putro et al., 2017).

The Non-Governmental Rural Agriculture Training Center (P4S) is a non-profit organization that manages agricultural training and education programs in groups (Solihin et al., 2019; Hamdani et al., 2020; Jamal et al., 2018) Porang's development in P4S Karya Tani, Tanjung Batu, and Ogan llir, South Sumatra is currently being promoted, with one example being the effect of Bidarti et al (2021a) is research. Bidarti et al (2021a) overcome the limitation of seeds as the main problem in porang planting in various places, including P4S Karya Tani, by doing tissue culture and utilizing seeds, because porang's seeds have polyembrio properties. 
P4S Karya Tani South Sumatra was transferred to the construction of the Agricultural Training Center (BPP) Lampung in 2011, in accordance with the policy of division of working areas (Amalia, 2020; Haryanto et al., 2017; Rahmawati et al., 2019) Until now, P4S Karya Tani has only had one central crop, rubber farming activities carried out by farmers who have received P4S Karya Tani training. According to Hardi (2014), the Non-Governmental Rural Agriculture Training Center (P4S) is a non-governmental organization that institutionally conducts education and training in agriculture and rural areas owned and managed by a nongovernmental organization, both individually and in groups. It is not a government agency.

It is critical to design and manufacture these washing machine porang's in order to meet market demand for the quality of the porang produced. Suharto et al (2018) emphasize that washing is an effective method for removing dirt that has become attached to the surface of porang's tubers. After harvesting, the process of cleaning porang's tubers of mud and soil. The process of cleaning porang's tubers by immersing, brushing, and spraying water continuously. According to Wijanarko et al (2015), the washing process with this machine is very supportive of its work operations, which include electric motors, panel controls, and washing cylinders. The washing process by an electric motor-driven washing machine is 100 percent more effective than the manual washing process, which only has a capacity of $200 \mathrm{~kg} /$ hour, whereas the capacity of the person's own washing machine is 200 / hour per process.

Porang's from trials and tissue culture development have currently planted an area of 4 ha of land owned by P4S Karya Tani Tanjung Batu. Planting and cultivating porang on P4S Karya Tani land is followed by planting porang on the land of P4S Karya Tani members, with as many as 56 P4S Karya Tani members. Tissue culture is still being used in P4S Karya Tani to create the seeds of many porang. In July-August, the cultivation of porang is planned to become one of the centers in the Tanjung Batu area of South Sumatra. Simultaneously, a study is being developed for the formation of a porang's supply chain in P4S Karya Tani, South Sumatra. P4S cooperation is not difficult to establish because one of the roles of P4S in empowering farmers is to develop a network of work and cooperation.

A target market supply chain is the achievement of the objectives of members in a supply chain in the supply chain of porang (Kuo et al., 2018) The support of porang, namely the processing plant of porang, is the target market of the supply chain of porang in P4S Karya Tani. The main exporter of porang's factories is currently located on the island of Java, with two factories on the island of Sumatra. Given the target market conditions, the most important P4S Karya Tani goal is to become a PT Paidi Indo Porang (PT PIP) Lampung representative as a customer partner of the products it manufactures.

PT Paidi Indo Porang (PT PIP) is very concerned with the quality of its employees:

(1) the level of drought of porang's tubers, which when broken can sound klek;

(2) There is at least 10 percent water content and it is not moldy;

(3) Porang cost up to 75000 IDR per kg (Bidarti et al., 2021b).

Farmers in P4S Karya Tani of South Sumatra must be able to meet the high level of quality of porang's results in getting super glucomanan flour by PT Paidi Indo Porang (PT PIP) Lampung representatives. One method for obtaining the high glucomannan levels anticipated by PT Paidi Indo Porang is to go through the initial process typically performed by its suppliers, namely washing, slicing, and drying fresh bulbs of farmers' crops (Kristinah et al., 2017)

According to the findings of the Yanuriati \& Basir studies (2020), high glucomannan produced from fresh tubers must first be isolated from the bulbs before being used with a simple isolation process. One of them is through the washing, slicing, and drying process. According to Suharto et al (2018), some farmers are often unaware of the process of washing, slicing, and drying are good, so the tubers are frequently processed themselves and done manually. This, particularly in the washing process, can result in less than optimal washing results, causing the price of porang to fall, even becoming unacceptable to exporters.

Several studies have been conducted, particularly on porang farmers in Java and particularly in East Java, to increase farmer prices, particularly the standard of washing, 
slicing, and drying desired by exporters (Alfath, 2020; Widjanarko et al., 2015) Designing tools to aid the process is one way to overcome the challenge of meeting these high standards. The tuber washer made by the porang is widely available on the market. However, it is prohibitively expensive, costing hundreds of millions of dollars (Suharto et al., 2018) However, it is made in an easy and straightforward manner. And it can be done at a reasonable cost, comparable to other washing machines (Womsiwor et al., 2018); Juwandi \& Mahmudi, 2020). The farmers of P4S Karya Tani of South Sumatra Ogan Ilir require this washing machine porang to meet market demand, which can be directly to the exporter of porang, PT Paidi Indo Porang (PT PIP) Lampung representatives.

Based on this, porang in P4S Karya Tani Ogan llir developed a washing machine in this study. This machine's development must be continued. A financial analysis of this techno-economy is urgently required. The purpose of this research is to conduct a technoeconomic financial analysis of washing machines porang in P4S Karya Tani, South Sumatra.

\section{METHODS OF RESEARCH}

In August to November 2021, students will spend 5 months studying at P4S Karya Tani, South Sumatra. The study's subject was a farmer who was a member of P4S Karya Tani, South Sumatra, along with up to 30 other porang. Method of financial analysis with criteria used in evaluating project investment in a variety of ways. The first step is to analyze the NPV (Net Present Value) in order to compare the current investment amount to the current cash flow amount. If the NPV is greater than the nol, the project is more likely to be carried out; conversely, if the NPV is less than the nol, the project is less likely to be carried out.

Both IRR (Internal Rate of Return) analyses are used to calculate the discount rate when the NPV is equal to zero and is expressed in percentage. If the IRR value is greater than the current interest rate, the project is declared viable. Third, the Net B / C (Net BenefitCost Ratio) analysis compares the amount of PV that is positive to the amount of PV that is negative. If $\mathrm{Net} B / C$ is greater than one, it is worthy; if Net $B / C$ is less than one, it is unworthy. Fourth, when determining eligibility, examine the Pay Back Period (PBP) to determine the time required to pay off all investment expenses.

\section{RESULTS AND DISCUSSION}

Training workshops were used in the early stages of the study as an introduction to the manufacture of washing machines porang's (Amorphophallus muelleri Blume.). Furthermore, a washing machine porang tool has been designed that is intended to get quality results. The prototype of this porang's tuber was driven by one power machine with a crank system. The working mechanism of this tool is by the principle of friction between the moving surface of the cylinder and the stationary surface of the rubber.

Porang are observed and recorded as a result of the washing machine for a technoeconomic financial analysis. Essentially, financial analysis seeks to assess the feasibility of a project in order to determine whether or not the project should be completed. Based on financial analysis, the price of the machine for him is $5700000 \mathrm{IDR} /$ machine.

The following assumptions are used in the financial analysis of washing machines porang's:

1. The price used in the calculation is the first-year constant price;

2. The average yield of cleaned tubers is 70 percent;

3. The cost of maintenance each year remains 5 percent of the cost of making the washing machine, while the cost of repairs is only 15 percent of the cost of making the washing machine at the end of the machine's economic life;

4. Porang's tubers are washed three hours per day for six days in a row;

5. Depreciation is calculated using the straight line method, with the residual value for facilities and equipment set at 25 percent of the initial value; 
6. First year production is 70 percent, second and third year production is 80 percent, and fourth year production is 100 percent;

7. The discount factor is based on the 17 percent investment rate of Bank Mandiri.

The investment fee represents the cost of producing a tuber washing machine worth 5700000 IDR. The NPV, PB IRR, and Net B/C ratio values are used to determine investment feasibility in a porang's tuber. The investment feasibility of making a porang's washing machine can be analyzed based on cash flow, which includes NPV, PBP, IRR, and Net B/C ratio. The difference between present value benefit and present value cost is the difference in net present value (NPV).

With a discount factor of 17 percent, the NPV value of making a porang's tuber is 15750500 IDR. This value indicates that the net benefit received over the next five years, calculated using the present value, is 15750500 IDR. Because NPV is positive, the investment is declared viable.

Payback Period (PBP) is one of the most basic capital budgeting calculation methods. The time required to close the initial investment of a project investment using the cash inflow generated by the investment is determined using this method. This investment has a PBP of 2.2 years, implying that it has been covered after 2 years and 2 months.

The Net Benefit Cost Ratio (Net B/C) is a value that compares a positive NPV to a negative NPV. If the net value of $B / C$ is greater than 1 , the NPV is greater than 0 , indicating that the investment is worthwhile. The net value of $\mathrm{B} / \mathrm{C}$ manufacturing a washing machine porang's is 2.50 , indicating that the investment is viable.

Internal Rate of Return (IRR) is an interest rate value that makes an investment NPV equal to zero, or an interest rate that indicates the amount of net present value (NPV) equal to the total amount of investment cost of making a person's tuber. The value of IRR investment in making porang's tuber washing machines is 65 percent. This value is higher than the prevailing interest rate, which is 17 percent, so the investment is declared viable.

Internal Rate of Return (IRR) is an interest rate value that makes an investment's net present value (NPV) equal to zero, or an interest rate that indicates the amount of net present value (NPV) equal to the total investment cost of producing a porang's tuber. The IRR investment in making washing machines porang's is worth 65 percent. This value is greater than the current interest rate of 17 percent, indicating that the investment is viable.

The conclusion is reached that investment is feasible based on the calculation of investment criteria. However, it is also necessary to evaluate the viability of investments if certain parameters, such as the selling price of porang tubers and the cost of exploitation, change. The sensitivity analysis outlines the assessment. Sensitivity analysis is performed in response to decreases in selling prices and increases in raw material prices. Invention is still possible if the price of raw materials for washing machines porang rises by up to 25 percent and the selling value of porang's tubers falls by up to 30 percent.

The values of investment criteria obtained from sensitivity analysis, namely if the price of raw materials increases by more than 30 percent or more than 25000 IDR per $\mathrm{kg}$, then invention is not feasible. And if the selling price of porang tubers falls by 30 percent or less than 10000 IDR per kg, invention is no longer feasible. Based on the calculations above, the net profit from the business of making washing machines porang was calculated to be 125150.33 IDR per month.

The assessment of investment criteria seeks to determine the project of producing a tuber. Based on the calculation of making a porang's tuber, the incremental value BCR = 1,020 was obtained. Theoretically, the results of incremental calculation BCR use of porang's tubers are quite profitable because the incremental value of BCR is greater than 1 , the NPV is 2575150.30 IDR, and the IRR is 50 percent of Break-Event Point (BEP).

The cost of the Break-Even Point (BEP) is calculated using the formula (20) based on the estimated age of the tool of 2 (th), and the result is as follows: BEP $=875.5(\mathrm{~kg}) /$ 5750275.25 IDR. That is, the Break-Even Point (BEP) will be reached if the tool can produce porang's tubers weighing $=875.5(\mathrm{~kg})$, or if the tool can already generate 5750275.25 IDR in profit. 


\section{CONCLUSION}

This independent inquiry began with the creation and formation of a porang's tuber (Amorphophallus muelleri Blume.). This machine can be used as a manual wash by a single person. The average capacity of a porang's tuber was $6.5 \mathrm{~kg} / \mathrm{hour}$, with a 94 percent washing efficiency. The Net Present Value (NPV) criteria of 15750500 IDR, Benefit Cost Ratio (BCR) of 2.50, profitability and Internal Rate of Return (IRR) of 65 percent, and Payback Period Value (PBP) covered at 2 years and 2 months were used in the technoeconomic financial feasibility test of a decent person's tuber.

Based on the porang's techno-economic capacity, the washing machine produced by P4S Karya Tani South Sumatra farmers is worth running after the tuber can produce $875.5 / \mathrm{kg}$ tubers, or the tool has earned 5750275.25 IDR.

\section{ACKNOWLEDGMENTS}

The publication of this article was funded by DIPA of Public Service Agency of Universitas Sriwijaya 2021. SP DIPA-0038.19/UN9/SB3.LP2M.PM/2021, on Augustus 18, 2021. In accordance with the Rector's Decree Number: 0006/UN9/SK.LP2M.PM/2021, on June 23, 2021.

\section{REFERENCES}

1. Alfath, R.G (2020). Perancangan Mesin Pencuci Umbi Porang Kapasitas $200 \mathrm{Kg} / \mathrm{Jam}$ dengan Metode Vdi 2221. Skripsi, Fakultas Teknologi Industri Program Studi Teknik Mesin Universitas Trisakti.

2. Anturida, Z., Azrianingsih, R., \& Wahyudi, D (2015) Pengaruh Jarak Tanam terhadap Pertumbuhan Porang (Amorphophallus muelleri Blume.) Pada Fase Pertumbuhan Kedua. Jurnal Biotropika, 3(3): 132-136.

3. Amalia, A (2020). Peran Pusat Pelatihan Pertanian dan Pedesaan Swadaya dan Hubungannya dengan Perilaku Petani dalam Pengembangan Usahatani Karet di Kelurahan Tanjung Batu Kabupaten Ogan Ilir. Skripsi. Fakultas Pertanian Universitas Sriwijaya, Tidak dipublikasikan.

4. Bidarti, A., Yulius, \& Purbiyanti, E (2021b) Regenerasi Bibit Unggul Porang (Amorphophalus Muelleri Blume) secara Kultur In Vitro dengan Pemberian Zat Pengatur Tumbuh Pupuk Organik Plus Liquitermy Fertilizer dan Pembentukan Rantai Pasok di Pusat Pelatihan Pertanian dan Pedesaan Swadaya (P4S) Tanjung Batu, Ogan Ilir. Penelitian Sateks. Tidak dipublikasikan. Indralaya. Universitas Sriwijaya.

5. Bidarti, A., Yulius, \& Purbiyanti, E (2021b). In Vitro Cultured and Supply Chain Porang in South Sumatra. Paper E-Proceeding. International Conference on Agribusiness and Rural Development. Universitas Muhammadiyah Yogyakarta. Yogyakarta. hlm. 232-240.

6. Hamdani, C (2020). Faktor - Faktor Yang Mempengaruhi Kinerja Berusaha Tani Petani Milenial Alumni Pelatihan Kewirausahaan Bagi Petani Muda Di Provinsi Jawa Tengah. Jurnal Agriwidya, 1(3): 61-73.

7. Hardi, R (2014). Opini Masyarakat dalam Program Pusat Pelatihan Pertanian Pedesaan Swadaya Masyarakat (P4s) Pemerintah Kabupaten Kampar. Jurnal Jom Fisip, 1(2): 1-12.

8. Haryanto Y., Sumardjo, Amanah, S., \& Tjitropranoto, P (2017). Efektivitas Peran Penyuluh Swadaya Dalam Pemberdayaan Petani Di Provinsi Jawa Barat. Jurnal Pengkajian dan Pengembangan Teknologi Pertanian, 20(2): 141-154.

9. Jamal, A (2018). Analisis Pendapatan Hot Cocoa (Studi Kasus (P4S) Cahaya Duta Palili Di Desa Bunga-Bunga, Kecamatan Matakali, Kabupaten Polewali Mandar). Jurnal Agrovital, 2(2): 35-40.

10. Juwandi, A., \& Mahmudi, H. Rancang Bangun Alat Pencuci Serbaguna Tipe Silinder Pada Mesin Pembuat Keripik. Prosiding Seminar Nasional Inovasi Teknologi, Universitas PGRI Kediri, 25 Juli 2020, hlm. 311-316. 
11. Kristinah. H., Suryanto, Suharto (2017) Ekstraksi Glukomannan Dari Umbi Tanaman Porang (Amorphophalus, Sp.). Prosiding Sentrinov. Polinema Malang. hlm.12-18.

12. Lontoh, A.P., Santosa, E. Kurniawati, A., \& Sari, M (2019) Yield Evaluation of Selected Clones Apomictic lles-lles (Amorphophallus muelleri Blume) on Second Growing Period. Journal Agronomy Indonesia, 47(2):171-179.

13. Putro, J.E., Handoko, C.R., Widodo, H., Rahmat, M.B., \& Arfianto, A.Z (2017). Pemanfaatan Teknologi Tenaga Matahari sebagai Sumber Energi bagi Petani Porang di Magetan. Prosiding Seminar Master PPN, hlm. 177-180.

14. Rahmawati, Baruwadi, M., \& Bahua, M.I (2019). Peran Kinerja Penyuluh dan Efektivitas Pelaksanaan Penyuluhan pada Program Intensifikasi Jagung. Jurnal Sosial Ekonomi Pertanian, 15(1): 56-70.

15. Siswanto B., \& Karamina, H (2016) Persyaratan Lahan Tanaman Porang (Amarphopallus ancophillus). Jurnal Buana Sains, 16(1): 57-70.

16. Solihin, Setiawan, I. , \& Wulandari, E (2019) Kinerja Pusat Pelatihan Pertanian Perdesaan Swadaya Berbasis Pesantren Di Jawa Barat. Jurnal Mimbar Agribisnis, 5(2): 304-315.

17. Suharto, Suryanto, Sarana, Santosa, T. B (2018). Rancang Bangun Mesin Pencuci Umbi Porang untuk Meningkatkan Kinerja Pengolahan Porang, Jurnal Teknologi Terapan, 4(2):108-112.

18. Yanuriati, A., \& Basir, D (2020) Peningkatan Kelarutan Glukomanan Porang (Amorphophallus muelleri Blume) dengan Penggilingan Basah dan Kering, agriTECH, 40 (4): $270-277$.

19. Womsiwor, O.O.O., Nurmaini, Zikri, A.Hendra, Amrizal, Yudistira,Batubara, F.Y (2018). Rancang Bangun Mesin Pengupas Dan Pencuci Singkong Tipe Horizontal. Journal of Applied Agricultural Science and Technology, 2(2):11-19.

20. Widjanarko, S.B., Widyastuti, E., \& Rozaq, F.I (2015). Pengaruh Lama Penggilingan Tepung Porang (Amorphophalus Muelleri Blume) dengan Metode Ball Mill (Cyclone Separator) terhadap Sifat Fisik dan Kimia Tepung Porang. Jurnal Pangan dan Agroindustri, 3(3): 867-877. 